\title{
Protective Effects of Solanum erianthum D. Don Leaf Extract on Lead-Induced Toxicity in Adult Wistar Rats
}

\author{
Olusegun Babalola*, John Agbi, Adeleke Badiora, Oladayo Areola \\ Department of Biochemistry, Obafemi Awolowo University, Ile-Ife, Osun State, Nigeria.
}

\begin{tabular}{|c|c|}
\hline ARTICLE INFO & ABSTRACT \\
\hline Article history: & \multirow{11}{*}{$\begin{array}{l}\text { The possible protective effects of the ethyl acetate fraction of Solanum erianthum ethanol leaf extract on lead- } \\
\text { induced toxicity in adult Wistar rats were investigated. Phytochemical constituents, antioxidant and membrane } \\
\text { stabilizing activities of the ethanol extract and its fractions were determined using standard procedures. Acute } \\
\text { and sub-chronic oral toxicity studies were carried out. The rats were treated orally with lead }(10 \mathrm{mg} / \mathrm{kg} \mathrm{b} \text {. wt) } \\
\text { and extract }(100 \mathrm{mg} / \mathrm{kg} \mathrm{b} \text {. wt). The blood samples, liver, and kidney were collected for the estimation of } \\
\text { biochemical and organ parameters, and histomorphological studies. The ethyl acetate fraction had the highest } \\
\text { antioxidant activities and high membrane stabilizing potentials when compared to the crude extract and other } \\
\text { fractions. Significant elevations were observed in plasma albumin, creatinine and urea levels in group treated } \\
\text { with lead only. The activities of plasma ALT and AST were significantly increased in group treated with lead } \\
\text { alone. Treatment with ethyl acetate fraction significantly decreased (p < } 0.05) \text { the elevated ALT, AST, urea and } \\
\text { creatinine levels. The histology evidence showed progressive degeneration of the liver and kidney tissues in lead } \\
\text { treated groups while the administration of } S \text {. erianthum showed appreciable degrees of protection to both the } \\
\text { liver and kidney. The study concluded that ethyl acetate fraction of } S \text {. erianthum has protective effects against } \\
\text { lead-induced toxicity in adult Wistar rats. }\end{array}$} \\
\hline Received on: $01 / 02 / 2016$ & \\
\hline Revised on: $05 / 03 / 2016$ & \\
\hline$/ 05 / 2016$ & \\
\hline Available online: $29 / 10 / 2016$ & \\
\hline Key words: & \\
\hline Lead-induced toxicity, & \\
\hline Solanum erianthum, ethyl & \\
\hline acetate fraction, acute & \\
\hline toxicity, sub-chronic toxicity, & \\
\hline histology. & \\
\hline
\end{tabular}

\section{INTRODUCTION}

Lead $(\mathrm{Pb})$ is a poisoning metal, which is ubiquitous in both organic (tetraethyl lead) and inorganic (lead nitrate, lead acetate, lead chloride) forms in the environment and is one of the major heavy metals used in industrial activities, like in automobile, paint, ceramic, plastic, etc industries because of its unique properties namely softness, high malleability, ductility, low melting point and resistance to corrosion (Shalan et al., 2005). This in turn has led to a manifold increase in the occurrence of free lead in biological systems and the inert environment, and hence remains a considerable occupational and public health problem, which is known to cause a number of adverse effects in both men and women (Flora et al., 2012). When lead is absorbed, it is conjugated in the liver and passed to the kidney, where a small quantity is excreted in urine and the

\footnotetext{
* Corresponding Author

Email: doctorbablo@yahoo.com;

Telephone: +2348037143321
}

rest accumulates in various body organs (Sidhu and Nehru, 2004). This affects many biological activities at the molecular, cellular and intercellular levels, which may result in morphological alterations that can remain even after lead level has fallen (Flora $e t$ al., 2006; Ibrahim et al., 2012). This may also result in lowering of seminal plasma protein with concomitant rise of free amino acid in blood in lead exposed workers as evidence of the alteration in protein metabolism, suggesting disturbance in cellular nutritional status, necessary for cell survival, and its proper function (Naha and Chowdhury, 2005). Many heavy metals, including $\mathrm{Pb}$, are known to induce over production of reactive oxygen species (ROS) and consequently enhance lipid peroxidation, decrease the saturated fatty acids and increase the unsaturated fatty acid contents of membranes (Malecka et al., 2001). Also, it has been shown that lead enhances the production of ROS in a variety of cells resulting in oxidative stress (Xienia et al., 2000) which represents an imbalance between the production of free radicals and the biological system's ability to readily detoxify the reactive intermediates or to repair the resulting damage (Flora et al., 2011). 
ROS are the byproducts of degenerative reactions in many tissues, which affect the regular metabolism by damaging the cellular components (Foyer and Noctor, 2002). In addition, ROS are highly reactive to membrane lipids, protein and DNA. They are believed to be the major contributing factors to stress injuries and to cause rapid cellular damage (Shehab et al 2010; Afify and El-Beltagi et al., 2011).

Under the influence of lead, onset of oxidative stress occurs on account of two different pathways operating simultaneously; first comes the generation of ROS, like hydroperoxides $\left(\mathrm{HO}^{2 \cdot}\right)$, singlet oxygen and hydrogen peroxide $\left(\mathrm{H}_{2} \mathrm{O}_{2}\right)$, and second, the antioxidant reserves become depleted (Flora et al., 2012).

Solanum erianthum, also known as potato tree, is a significant source of natural antioxidants, which might be helpful in preventing the progress of various oxidative stresses (Mahadev et al. (2015). It is a fast growing, evergreen shrub or small tree, reaching a height of $4-10 \mathrm{~m}$ and stem up to $20 \mathrm{~cm}$ in diameter, unarmed, densely woolly hairy with soft stellate hairs (Mild, 2009). Potato tree can be found at elevations from sea level to $1,500 \mathrm{~m}(4,900 \mathrm{ft})$ in a variety of habitats, including riparian zones, dry forests (Felger et al., 2001), and moist forests. It often grows in disturbed areas (Hammer, 2004), such as roadsides, fields, and waste places, and may be considered a weed (Modise and Mogotsi, 2008).

Solanum erianthum possesses steroidal saponins and steroidal alkaloids that are used in the pharmaceutical industry as steroid precursors to produce anti-inflammatory corticosteroids, contraceptive steroids, and anabolic steroids (Modise and Mogotsi, 2008). In West Africa, a decoction of the leaves is used as a diuretic and purgative to cure malaria, leprosy and venereal diseases and to stimulate the liver functions (Modise and Mogotsi, 2008). Essential oils in the fruits and leaves of $S$. erianthum have been studied for their cytotoxicity as well as their traditional uses in medicine, especially for skin diseases and stomach-related ailments (Essien et al., 2012).

Lead toxicity has been recognized as a major public health risk, particularly in developing countries, resulting in various deleterious effects on the renal and hepatic systems, mainly through increased oxidative stress. Research has shown that Solanum erianthum contains phytochemicals with antioxidant activities that can prevent or subdue the generation of oxidative stress. The study therefore investigated the possibility of utilising the leaf extract of Solanum erianthum in the management of leadinduced toxicity.

\section{MATERIALS AND METHODS}

\section{Collection and Identification of Plant Material}

Fresh leaves of Solanum erianthum D. Don were collected from Sekona Village, Osun State, Nigeria. The plant was identified and authenticated at IFE Herbarium, Department of Botany, Obafemi Awolowo University, Ile-Ife, Nigeria. The voucher specimen was deposited in the Herbarium and the specimen identification number is IFE-17429.

\section{Reagents and Chemicals}

All the reagents used in the study were of analytical grade and were obtained from reputable sources. 1, 1-diphenyl-2picrylhydrazyl hydrate (DPPH), Follin-Ciocalteu's phenolic reagent, sodium carbonate, sodium hydroxide, Gallic acid, Ascorbic acid (Vitamin C), ferric chloride, Quercetin and aluminium chloride were obtained from Sigma Fine Chemicals Limited, Upsalla, Sweden and British Drug House (BDH) Chemicals Limited, London.

Alanine aminotransferase, aspartate aminotransferase, total bilirubin, urea, creatinine and albumin diagnostic kits were obtained from Randox Laboratories Ltd, United Kingdom. All solutions, buffers and reagents were prepared with glass distilled water and stored in the refrigerator at $4{ }^{\circ} \mathrm{C}$.

\section{Experimental Animals}

Adult Wistar rats used in this study were obtained from the animal house, Faculty of Pharmacy, Obafemi Awolowo University, Ile-Ife, Nigeria. The animals were acclimatized for eight weeks, fed with standard commercial pellet diet obtained from Ogooluwa feeds, Ile-Ife and given access to water ad libitum. The rats were housed under standard conditions, at natural light and dark cycle.

\section{Preparation of Extract and Fractions of Solanum erianthum}

The dried leaves of Solanum erianthum $(2.0 \mathrm{~kg})$ was ground into fine smooth powder using impact mill. The powdered leaves $(500 \mathrm{~g})$ was soaked in $70 \%$ ethanol $(7.5 \mathrm{~L})$ for 72 hours, and filtered afterwards with a double layered cheese cloth. This was then filtered using filter paper (Whatman No. 1) and concentrated to dryness using a rotary evaporator Model ED-100. The ethanol extract $(20 \mathrm{~g})$ was taken up in distilled water $(200 \mathrm{ml})$. The filtrate was partitioned sequentially with hexane $(100 \mathrm{ml} \times 4)$, ethyl acetate $(100 \mathrm{ml} \mathrm{x} \mathrm{4)}$ and butanol $(100 \mathrm{ml} \mathrm{x} \mathrm{4)}$ in capped separating funnel. The content was vigorously shaken, allowed to settle and carefully separated.

The same fractions were combined and concentrated in rotary evaporator separately. The fractions and aqueous residue were dried, weighed, labeled and kept in the desiccators until needed for further analyses.

\section{Phytochemical Screening of the Extract and Fractions}

The phytochemical screening of the extract and fractions was carried out using standard procedures as described by the earlier reports of Sofowora (2006).

\section{Membrane Stabilization Activity}

The red blood cell membrane stabilizing activity assay was carried out using the method of Oyedapo et al. (2010). 


\section{Preparation of Bovine Red Blood Cell}

Fresh bovine blood samples were collected in an anticoagulant (trisodium citrate 3.8\%). Blood samples were centrifuged at $3000 \mathrm{rpm}$ on a Bench centrifuge Model 800D for 10 minutes at room temperature. The supernatants (plasma) were carefully removed while the packed red blood cell was washed in fresh normal saline $(0.85 \% \mathrm{w} / \mathrm{v} \mathrm{NaCl})$. The process of washing and centrifugation were repeated four times until the supernatants were clear. Then, bovine erythrocytes $(2 \% \mathrm{v} / \mathrm{v})$ were prepared as reported by Oyedapo et al. (2010).

\section{Membrane Stabilizing Activity}

The membrane stabilizing activity assay was carried out using the method of Oyedapo et al. (2010) using $2 \%(\mathrm{v} / \mathrm{v})$ bovine erythrocyte suspension while diclofenac was used as standard drug. The assay mixtures consisted of $1 \mathrm{ml}$ of hyposaline $(0.25 \%$ w/v) sodium chloride, $0.5 \mathrm{ml}$ of $0.15 \mathrm{M}$ sodium phosphate buffer, $\mathrm{pH} 7.4,0.5 \mathrm{ml}$ of $2 \%$ (v/v) bovine erythrocytes suspension, $0.0-$ $1.4 \mathrm{ml}$ of drug (standard, extract and fractions) and final reaction mixtures were made up to $4.0 \mathrm{ml}$ with normal saline. Drug was omitted in the blood control, while the drug control did not contain the erythrocytes suspension.

The reaction mixtures were incubated at $56^{\circ} \mathrm{C}$ for 30 minutes on a water bath, followed by centrifugation at $5000 \mathrm{rpm}$ on Gallenkamp Bench Centrifuge for 10 minutes at room temperature. The absorbance of the released haemoglobin was read at $560 \mathrm{~nm}$. The percentage membrane stability was estimated using the expression:

$$
\begin{aligned}
& \text { Percentage membrane stability } \\
& =\frac{100-(\text { Abs of test drug }- \text { Abs of drug control })}{\text { Abs of blood control }} \times 100
\end{aligned}
$$

Where the blood control represents $100 \%$ lysis or zero percent stability.

\section{In vitro Antioxidant Studies}

\section{Ferric Reducing Antioxidant Power (FRAP) Assay}

The FRAP assay used antioxidants as reductants in a redox linked colometric method with absorbance measured with spectrophotometer (Benzie and Strain, 1999).

\section{Determination of Total Phenol Content}

The total phenol content of the extract/fractions of Solanum erianthum was determined using the Folin - Ciocalteu's method of Singleton and Rossi (1965) as described by Gulcin et al. (2003). The total phenol content of the plants was expressed as mg gallic acid equivalent (GAE)/g fresh weight.

\section{Determination of 1, 1-Diphenyl-2-Picrylhydrazyl Hydrate (DPPH) Radical Scavenging Activity}

The hydrogen or radical scavenging properties of the extracts was determined using the stable radical 1, 1-diphenyl-2- picrylhydrazyl hydrate (DPPH) according to the method of Blois (1958) and as described by Brace (2001).

The antioxidant activity (AA) was calculated using the formula:

$$
\begin{aligned}
& \text { Percentage scavenging activity } \\
& =\frac{\text { Absorbance (control) }- \text { Absorbance }(\text { sample }) \times 100}{\text { Absorbance (control) }}
\end{aligned}
$$

The 50\% inhibitory concentration $\left(\mathrm{IC}_{50}\right)$ was obtained from a linear regression plot of percentage inhibition against concentration of the extract.

\section{Determination of Total Flavonoid Content}

The determination of the total flavonoid content of the plant extract/fractions was based on the aluminium chloride colorimetric method according to the method of Zhilen et al. (1999) and as described by Miliauskas et al. (2004). The total flavonoid content of the plant extract/fractions was expressed as mg Quercetin equivalents per gram of the plant extract.

\section{Acute Toxicity Study $\left(\mathbf{L D}_{50}\right.$ Determination)}

Acute toxicity study was carried out in two phases, according to the procedure of Lorke (1983) with slight modifications. The $\mathrm{LD}_{50}$ was estimated from the plot of percentage mortality versus logarithm of concentrations.

\section{Sub-chronic Toxicity Study}

The study was carried out as follows; a total of thirty-five adult albino rats [Wistar strain (weight between 140 - $260 \mathrm{~g}$ )] were used for the experiment and were randomly grouped into seven groups (five rats in each group) and were subjected to every-otherday oral dose treatments for forty-two days as follows: Rats in group 1 (control) were administered normal saline. Rats in group 2 were administered lead only $(10 \mathrm{mg} / \mathrm{kg}$ b. wt). Rats in group 3 were administered extract only $(100 \mathrm{mg} / \mathrm{kg} \mathrm{b}$. wt). Rats in group 4 were co-administered lead $(10 \mathrm{mg} / \mathrm{kg} \mathrm{b}$. wt $)+$ ethyl acetate fraction $(100 \mathrm{mg} / \mathrm{kg} \mathrm{b}$. wt). Rats in group 5 were pre-administered lead $(10 \mathrm{mg} / \mathrm{kg} \mathrm{b}$. wt) + ethyl acetate fraction $(100 \mathrm{mg} / \mathrm{kg} \mathrm{b}$. wt). Rats in group 6 were post-administered lead $(10 \mathrm{mg} / \mathrm{kg} \mathrm{b}$. wt $)+$ ethyl acetate fraction $(100 \mathrm{mg} / \mathrm{kg} \mathrm{b}$. wt). Rats in group 7 (positive control) were administered lead $(10 \mathrm{mg} / \mathrm{kg}$ b. wt $)+$ vitamin E (100 $\mathrm{mg} / \mathrm{kg} \mathrm{b}$. wt).

The rats were weighed before the commencement of treatments and thereafter weighed weekly throughout the duration (42 days) of the study.

At the end of the 42-day experiment, the rats fasted 24 hours and were sacrificed. The blood samples were collected by cardiac puncture into heparinized bottles for estimation of biochemical parameters and the organs such as the liver and kidney were excised, weighed, rinsed with normal saline and stored for further biochemical and histomorphological studies. 


\section{Preparation of Blood Plasma and Tissue Homogenate}

The blood collected in heparinized bottle was centrifuged using Bench centrifuge (Model 90-2) at $4000 \mathrm{rpm}$ for $10 \mathrm{~min}$ to separate supernatant and residue. The supernatant (plasma) was collected using dry Pasteur pipette, stored in sterile vial and kept in freezer for biochemical analyses. Liver and kidney were surgically removed and a $10 \%(\mathrm{w} / \mathrm{v})$ tissue homogenates were prepared by homogenizing the liver and kidney separately in phosphate buffer solution, $\mathrm{pH} 7.4$.

The homogenates were centrifuged at $4000 \mathrm{rpm}$ for 15 minutes and the supernatant was collected as a source for the assessment of hepatic marker enzymes, and kidney function parameters.

\section{Estimation of Creatinine Concentration}

The creatinine concentration was estimated using Jaffe'salkaline picrate method as described by Chawla (1999) using Randox kit.

\section{Estimation of Urea Concentration}

Plasma urea was estimated as described by Weatherburn (1967) using Randox kits.

\section{Estimation of Protein Concentration}

Biuret reaction as described by Gornall et al. (1949) using bovine albumin as standard was used for the estimation of the total protein from the extract.

\section{Estimation of Albumin Concentration}

The bromocresol purple (BCP albumin) procedure as modified (Pinnell and Northam, 1978) was employed to estimate the concentration of albumin in the plasma using commercially available Randox kit.

\section{Estimation of Total Bilirubin Concentration}

Bilirubin concentration in the serum was determined according to the method of Jendrassisk and Grof (1938). Total bilirubin was determined in the presence of caffeine, which releases albumin bound bilirubin, by the reaction with diazotized sulphanilic acid.

\section{Assay for Alanine Aminotransferase (EC 2.6.1.2) Activity}

The activity of alanine aminotransferase was assayed based on the colorimetric method of Reitman and Frankel (1957) using a commercially available Randox kit.

\section{Assay of Aspartate Aminotransferase (EC 2.6.1.1) Activity}

The activity of aspartate aminotransferase was assayed based on the colorimetric method of Reitman and Frankel (1957) using a commercially available Randox kit.

\section{Histopathological Analysis}

Portions of the tissue from liver and kidney were used for histopathological examination. Histopathological analysis was carried out using standard methods.

\section{Statistical Analysis}

Data are expressed as mean \pm SEM. Comparisons between different groups were done using one way analysis of variance (ANOVA) followed by Tukey - Kramer multiple comparisons test. A probability level of less than 0.05 was accepted as statistically significant.

\section{RESULTS}

The phytochemical constituents of the various plant materials are given in the Table 1 below. The results show the presence of various secondary metabolites (phytochemicals) like tannin, saponin, alkaloids, flavonoids, cardiac glycoside etc. the inferences of these phytochemicals were based on the formation of coloured precipitate formed after carrying out the various tests.

Table 1: Phytochemical Constituents of Solanum erianthum Ethanol Leaf Extract and its Fractions.

\begin{tabular}{lccccc}
\hline Extract/Fraction & CEE & n-HF & EAF & n-BF & AqF \\
\hline Phytochemicals & & & & & \\
Alkaloids & ++ & + & + & + & + \\
Cardiac Glycosides & ++ & + & + & ++ & + \\
Flavonoids & ++ & + & ++ & + & + \\
Saponins & +++ & - & - & + & +++ \\
Tannins & ++ & - & + & ++ & ++ \\
Triterpenes & ++ & + & + & + & + \\
Steroids & + & + & + & - & -
\end{tabular}

$(+)$ represent positive result and $(-)$ represent negative result, $\mathrm{CEE}=\mathrm{Crude}$ ethanol fraction, $\mathrm{n}-\mathrm{HF}=\mathrm{n}-\mathrm{Hexane}$ fraction, $\mathrm{EAF}=$ Ethyl acetate fraction, $\mathrm{AqF}=$ Aqueous fraction and $\mathrm{n}-\mathrm{BF}=\mathrm{Butanol}$ fraction.

Table 2 showed the yield of ethanol extract from $500 \mathrm{~g}$ of dried powdered leaves of Solanum erianthum was $72.8 \mathrm{~g}$ representing $14.56 \%$ of the starting materials while the yield of the fractions was given as $41.20 \%(8.24 \mathrm{~g})$ for aqueous residues, $22.04 \%$ (4.408 g) for n-butanol, 20.25\% (4.05 g) for ethyl acetate fractions and $4.8 \%(0.96 \mathrm{~g})$ for $\mathrm{n}$-hexane,

Table 2: Percentage Yields and Concentrations of Total Phenol and Total Flavonoid Constituents Contained in S. erianthum Leaves.

\begin{tabular}{|c|c|c|c|}
\hline $\begin{array}{l}\text { Extract/ } \\
\text { Fraction }\end{array}$ & $\begin{array}{c}\text { Extraction } \\
\text { Yields } \\
\% \text { Yield (w/w) }\end{array}$ & $\begin{array}{c}\text { Total Flavonoid } \\
\text { Content } \\
\text { QE }(\mathrm{mg} / \mathrm{g})\end{array}$ & $\begin{array}{c}\text { Total Phenol } \\
\text { Content } \\
\text { GAE }(\mathrm{mg} / \mathrm{g})\end{array}$ \\
\hline Crude ethanol & 14.56 & $11.47 \pm 1.80$ & $42.74 \pm 2.36$ \\
\hline Ethyl acetate & 20.25 & $74.79 \pm 2.99$ & $98.38 \pm 5.31$ \\
\hline n-Butanol & 22.04 & $11.22 \pm 4.79$ & $76.70 \pm 0.29$ \\
\hline n-Hexane & 4.8 & $39.10 \pm 0.90$ & $8.78 \pm 5.90$ \\
\hline Aqueous & 41.20 & $10.78 \pm 0.00$ & $18.53 \pm 8.55$ \\
\hline
\end{tabular}

The results of 1, 1-diphenyl-2-picrylhydrazyl hydrate (DPPH) radical scavenging activity of crude ethanol extract and fractions of Solanum erianthum is shown in Table 3. 
Table 3: 1, 1-Diphenyl-2-Picrylhydrazyl Hydrate (DPPH) Radical Scavenging Activity of S. erianthum Ethanol Leaf Extract and its Fractions.

\begin{tabular}{|c|c|c|c|c|c|c|}
\hline $\begin{array}{l}\text { Extract/Fraction } \\
\text { Conc. }(\mathrm{mg} / \mathrm{ml})\end{array}$ & C EE & EAF & n-BF & $\mathbf{A q F}$ & n-HF & Vit-E \\
\hline & \multicolumn{6}{|c|}{ Percentage Inhibition } \\
\hline 0.5 & $44.03 \pm 0.95$ & $67.15 \pm 0.72$ & $49.11 \pm 1.62$ & $14.79 \pm 0.43$ & $15.07 \pm 1.71$ & $89.61 \pm 0.23$ \\
\hline 0.25 & $28.54 \pm 1.63$ & $50.20 \pm 1.21$ & $31.93 \pm 1.10$ & $8.58 \pm 1.47$ & $7.09 \pm 0.27$ & $70.92 \pm 7.74$ \\
\hline 0.125 & $18.21 \pm 0.96$ & $28.47 \pm 0.40$ & $15.63 \pm 0.83$ & $2.37 \pm 0.86$ & $-0.36 \pm 0.96$ & $22.95 \pm 4.23$ \\
\hline 0.0625 & $4.52 \pm 0.67$ & $17.98 \pm 0.66$ & $12.64 \pm 0.72$ & $2.48 \pm 1.00$ & $2.74 \pm 0.32$ & $7.02 \pm 3.54$ \\
\hline 0.03125 & $3.83 \pm 0.78$ & $7.60 \pm 1.26$ & $6.37 \pm 0.67$ & $-0.06 \pm 0.59$ & $-2.56 \pm 0.21$ & $3.91 \pm 1.69$ \\
\hline 0.01563 & $0.93 \pm 1.01$ & $2.47 \pm 0.70$ & $-1.61 \pm 2.36$ & $2.20 \pm 2.63$ & $-5.84 \pm 1.19$ & $4.06 \pm 5.58$ \\
\hline \multirow[t]{2}{*}{0.00781} & $1.33 \pm 0.78$ & $-0.23 \pm 0.38$ & $-1.77 \pm 2.67$ & $-2.65 \pm 0.40$ & $-4.88 \pm 0.95$ & - \\
\hline & \multicolumn{6}{|c|}{$\mathrm{IC}_{50}(\mathrm{mg} / \mathrm{ml})$} \\
\hline
\end{tabular}

Data are expressed as Mean $\pm \mathrm{SEM},(\mathrm{n}=3) . \mathrm{CEE}=$ Crude ethanol extract, $\mathrm{EAF}=$ Ethyl acetate fraction, $\mathrm{n}-\mathrm{BF}=\mathrm{Butanol}$ fraction, AqF $=\mathrm{Aqueous}$ fraction, $\mathrm{n}-\mathrm{HF}$

$=$ Hexane fraction, Vit $-\mathrm{E}=$ Vitamin $\mathrm{E}$ and $\mathrm{IC}_{50}=$ Half maximal inhibitory concentration .

Table 4: The Ferric Reducing Antioxidant Power (FRAP) Assay of S. erianthum Crude Ethanol Extract and its Fractions.

\begin{tabular}{cc}
\hline Extract/Fraction & Ascorbic Acid Equivalent (mg/g) \\
\hline Crude ethanol extract & $76.59 \pm 2.88$ \\
Ethyl acetate fraction & $144.25 \pm 0.97$ \\
n-Butanol fraction & $63.11 \pm 2.60$ \\
n-Hexane fraction & $102.45 \pm 6.78$ \\
Aqueous fraction & $16.92 \pm 0.34$ \\
\hline
\end{tabular}

Data are expressed as mean \pm S.E.M $(\mathrm{n}=3)$.

Table 5: Acute Toxicity Test of Crude Ethanol Extract of Solanum erianthum in Mice.

\begin{tabular}{ccc}
\hline $\begin{array}{c}\text { Dose } \\
(\mathbf{m g} / \mathbf{k g} \text { Body Weight })\end{array}$ & Number of Animals & Mortality \\
\hline First Phase & & $0 / 3$ \\
10 & 3 & $0 / 3$ \\
100 & 3 & $0 / 3$ \\
\hline Second Phase & 3 & $0 / 3$ \\
\hline 1600 & 3 & $0 / 3$ \\
\hline 5000 & 3 & $0 / 3$ \\
\hline
\end{tabular}

Table 6: Membrane Stabilizing Activities of Crude Ethanol Extract and Fractions of S. erianthum on Bovine Red Blood Cell.

\begin{tabular}{|c|c|c|c|c|c|c|}
\hline $\begin{array}{c}\text { Extract/Fraction } \\
\text { Conc. }(\mathrm{mg} / \mathrm{ml})\end{array}$ & C EE & EAF & n-BF & $\mathbf{A q F}$ & n-HF & Diclofenac \\
\hline & \multicolumn{6}{|c|}{ Percentage Stability } \\
\hline 0.05 & $9.23 \pm 0.22$ & $10.10 \pm 0.37$ & $8.04 \pm 0.40$ & $8.12 \pm 0.42$ & $2.13 \pm 0.65$ & $9.68 \pm 0.30$ \\
\hline 0.10 & $8.55 \pm 0.29$ & $15.38 \pm 0.74$ & $8.76 \pm 0.78$ & $11.59 \pm 0.23$ & $3.20 \pm 1.37$ & $12.11 \pm 1.46$ \\
\hline 0.15 & $17.30 \pm 0.66$ & $19.97 \pm 0.28$ & $10.04 \pm 0.29$ & $10.14 \pm 0.51$ & $1.99 \pm 0.56$ & $17.06 \pm 0.20$ \\
\hline 0.20 & $22.28 \pm 1.86$ & $21.10 \pm 0.47$ & $15.53 \pm 0.29$ & $18.84 \pm 0.12$ & $4.73 \pm 0.48$ & $19.48 \pm 1.30$ \\
\hline 0.25 & $22.49 \pm 0.22$ & $22.44 \pm 1.45$ & $13.64 \pm 0.38$ & $17.39 \pm 0.53$ & $3.66 \pm 0.25$ & $23.82 \pm 1.03$ \\
\hline 0.30 & $33.97 \pm 0.47$ & $29.17 \pm 0.19$ & $21.02 \pm 0.29$ & $24.64 \pm 0.81$ & $8.95 \pm 0.40$ & $27.42 \pm 0.30$ \\
\hline
\end{tabular}

Data are expressed as Mean $\pm \mathrm{SEM},(\mathrm{n}=3)$. CEE $=$ Crude ethanol extract, $\mathrm{EAF}=$ Ethyl acetate fraction, $\mathrm{n}-\mathrm{BF}=\mathrm{Butanol}$ fraction, AqF $=\mathrm{Aqueous}$ fraction, $\mathrm{n}-\mathrm{HF}$ $=$ Hexane fraction, Standard drug $=$ Diclofenac and Conc. $=$ Concentration.

In the DPPH assay, ethyl acetate fraction gave the highest activity with an $\mathrm{IC}_{50}$ of $0.33 \pm 0.00$, indicating that the activity increases with the increase in concentration (i.e. the activity was concentration dependent). Other fractions and crude ethanol extract gave the $\mathrm{IC}_{50}$ of $0.53 \pm 0.01,0.48 \pm 0.01,1.60 \pm$ $0.05,1.39 \pm 0.10 \mathrm{mg} / \mathrm{ml}$ for crude ethanol extract, n-butanol fraction, aqueous fraction and n-hexane fraction respectively.

The ferric reducing antioxidant power (FRAP) assay result shows a concentration dependent change when the FRAP values of the crude extract and fractions were determined. The plant extract and fraction showed that the S. erianthum had $76.59 \pm$ $2.88,144.25 \pm 0.97,63.11 \pm 2.60,102.45 \pm 6.78$ and $16.92 \pm 0.34$ mg AAE/g for crude ethanol leaf extract, ethyl acetate, n-butanol, n-hexane and aqueous fractions respectively with ethyl acetate $(144.25 \pm 0.97)$ having the highest activity, and aqueous residues $(16.92 \pm 0.34)$ having the lowest activity as shown in Table 4 .

The results of the acute toxicity test are presented in Table 5 while the membrane stabilizing activity of the extract and fractions of $S$. erianthum on bovine red blood cell exposed to both heat and hypotonic induced lyses are shown in Table 6. The effect of lead and crude ethanol extract and fractions of $S$. erianthum on average body weight of adult wistar rats in the first and last week of administration are shown in Table 7. There was significant increase in the percentage change in body weight of the rats in the control group, and there was significant decrease in the percentage change in toxicant groups. 
Table 7: Effect of Solanum erianthum on Average Body Weight.

\begin{tabular}{cccc}
\hline Group & $\begin{array}{c}\text { Initial } \\
\text { Weight } \mathbf{( g )}\end{array}$ & $\begin{array}{c}\text { Final Weight } \\
(\mathbf{g})\end{array}$ & $\begin{array}{c}\text { Percentage Change in } \\
\text { Weight } \mathbf{( \% )}\end{array}$ \\
\hline A & $152.5 \pm 15.34$ & $190.0 \pm 13.54$ & 24.59 \\
B & $182.0 \pm 4.64$ & $214.0 \pm 6.78$ & 17.58 \\
C & $180.0 \pm 6.52$ & $228.0 \pm 5.83$ & 26.67 \\
D & $156.0 \pm 2.45$ & $177.0 \pm 5.83$ & 13.46 \\
E & $148.0 \pm 4.90$ & $184.0 \pm 10.65$ & 24.32 \\
F & $175.0 \pm 3.16$ & $196.0 \pm 9.14$ & 12.00 \\
G & $166.0 \pm 3.67$ & $200.0 \pm 10.95$ & 20.48 \\
\hline
\end{tabular}

Keys: $\mathrm{A}=$ Control

$\mathrm{B}=$ Toxicant Alone (Lead $10 \mathrm{mg} / \mathrm{kg}$ body weight $)$

$\mathrm{C}=$ Extract Alone $(100 \mathrm{mg} / \mathrm{kg}$ body weight $)$

$\mathrm{D}=$ Lead $(10 \mathrm{mg} / \mathrm{kg})+$ Ethyl Acetate Fraction $(100 \mathrm{mg} / \mathrm{kg}$ body weight $)$ $\mathrm{E}=$ Pre Lead $(10 \mathrm{mg} / \mathrm{kg})+$ Ethyl Acetate Fraction $(100 \mathrm{mg} / \mathrm{kg}$ body weight $)$ $\mathrm{F}=$ Post Lead $(10 \mathrm{mg} / \mathrm{kg})+$ Ethyl Acetate Fraction $(100 \mathrm{mg} / \mathrm{kg}$ body weight $)$ $\mathrm{G}=\mathrm{Lead}(10 \mathrm{mg} / \mathrm{kg})+$ Vitamin $\mathrm{E}(100 \mathrm{mg} / \mathrm{kg}$ body weight $)$

The effects of lead intoxication and treatment with extract and fractions of $S$. erianthum on the excretory organs are shown in Table 8. There was slight difference in their weight. The toxicant treated groups showed decreased relative organs' weight.

Table 8: Effect of S. erianthum on Relative Weight of Kidney and Liver of Adult Wistar Rats.

\begin{tabular}{cccc}
\hline Group & Liver $(\mathbf{g})$ & Right Kidney $(\mathbf{g})$ & Left Kidney $(\mathbf{g})$ \\
\hline A & $3.15 \pm 0.23$ & $0.31 \pm 0.02$ & $0.31 \pm 0.01$ \\
B & $3.30 \pm 0.12$ & $0.28 \pm 0.01$ & $0.30 \pm 0.01$ \\
C & $3.12 \pm 0.09$ & $0.26 \pm 0.01$ & $0.25 \pm 0.01$ \\
D & $3.42 \pm 0.04$ & $0.32 \pm 0.01$ & $0.31 \pm 0.01$ \\
E & $3.28 \pm 0.11$ & $0.31 \pm 0.01$ & $0.31 \pm 0.01$ \\
F & $3.08 \pm 0.08$ & $0.34 \pm 0.01$ & $0.30 \pm 0.01$ \\
G & $3.23 \pm 0.11$ & $0.32 \pm 0.01$ & $0.30 \pm 0.01$ \\
\hline
\end{tabular}

Keys: $\mathrm{A}=$ Control

$\mathrm{B}=$ Toxicant Alone (Lead $10 \mathrm{mg} / \mathrm{kg}$ body weight)

$\mathrm{C}=$ Extract Alone $(100 \mathrm{mg} / \mathrm{kg}$ body weight $)$

$\mathrm{D}=$ Lead $(10 \mathrm{mg} / \mathrm{kg})+$ Ethyl Acetate Fraction $(100 \mathrm{mg} / \mathrm{kg}$ body weight $)$

$\mathrm{E}=$ Pre Lead $(10 \mathrm{mg} / \mathrm{kg})+$ Ethyl Acetate Fraction $(100 \mathrm{mg} / \mathrm{kg}$ body weight $)$

$\mathrm{F}=$ Post Lead $(10 \mathrm{mg} / \mathrm{kg})+$ Ethyl Acetate Fraction $(100 \mathrm{mg} / \mathrm{kg}$ body weight $)$

$\mathrm{G}=\mathrm{Lead}(10 \mathrm{mg} / \mathrm{kg})+$ Vitamin $\mathrm{E}(100 \mathrm{mg} / \mathrm{kg}$ body weight $)$

Table 9: Effect of Solanum erianthum on Creatinine, Urea and Total Protein Levels of Adult Wistar Rats.

\begin{tabular}{|c|c|c|c|}
\hline Group & $\begin{array}{c}\text { Creatinine in } \\
\text { Plasma }(\mathrm{mg} / \mathrm{dl})\end{array}$ & $\begin{array}{c}\text { Urea in } \\
\text { Plasma (mg/dl) }\end{array}$ & $\begin{array}{c}\text { Total Protein in Kidney } \\
(\mathrm{mg} / \mathrm{ml})\end{array}$ \\
\hline $\mathrm{A}$ & $1.38 \pm 0.66$ & $39.15 \pm 2.70$ & $2.31 \pm 0.07$ \\
\hline B & $2.44 \pm 0.87$ & $57.71 \pm 3.31^{\mathrm{a}}$ & $2.25 \pm 0.24$ \\
\hline $\mathrm{C}$ & $1.51 \pm 0.30$ & $39.81 \pm 4.13^{b}$ & $1.74 \pm 0.18$ \\
\hline $\mathrm{D}$ & $1.33 \pm 0.55^{\mathbf{b}}$ & $37.04 \pm 7.05^{b}$ & $1.73 \pm 0.11$ \\
\hline $\mathrm{E}$ & $1.31 \pm 0.31^{\mathbf{b}}$ & $35.18 \pm 13.6^{b}$ & $1.11 \pm 0.14^{\mathbf{a}, \mathbf{b}}$ \\
\hline $\mathrm{F}$ & $1.57 \pm 0.50$ & $30.55 \pm 10.25^{b}$ & $1.47 \pm 0.19$ \\
\hline $\mathrm{G}$ & $1.73 \pm 0.26$ & $37.18 \pm 6.70^{b}$ & $1.24 \pm 0.30^{\mathbf{a}, \mathbf{b}}$ \\
\hline \multicolumn{4}{|c|}{$\begin{array}{l}\mathbf{a}=\text { significantly different from the control group at } \mathrm{p}<0.05 \\
\mathbf{b}=\text { significantly different from lead-treated group at } \mathrm{p}<0.05 \\
\mathbf{c}=\text { significantly different from extract-treated group at } \mathrm{p}<0.05\end{array}$} \\
\hline \multicolumn{4}{|c|}{$\begin{array}{l}\text { Keys: A = Control } \\
\mathrm{B}=\text { Toxicant Alone }(\mathrm{Lead} 10 \mathrm{mg} / \mathrm{kg} \text { body weight }) \\
\mathrm{C}=\text { Extract Alone }(100 \mathrm{mg} / \mathrm{kg} \text { body weight }) \\
\mathrm{D}=\mathrm{Lead}(10 \mathrm{mg} / \mathrm{kg})+\text { Ethyl Acetate Fraction }(100 \mathrm{mg} / \mathrm{kg} \text { body weight }) \\
\mathrm{E}=\text { Pre Lead }(10 \mathrm{mg} / \mathrm{kg})+\text { Ethyl Acetate Fraction }(100 \mathrm{mg} / \mathrm{kg} \text { body weight }) \\
\mathrm{F}=\text { Post Lead }(10 \mathrm{mg} / \mathrm{kg})+\text { Ethyl Acetate Fraction }(100 \mathrm{mg} / \mathrm{kg} \text { body weight }) \\
\mathrm{G}=\text { Lead }(10 \mathrm{mg} / \mathrm{kg})+\text { Vitamin E }(100 \mathrm{mg} / \mathrm{kg} \text { body weight })\end{array}$} \\
\hline
\end{tabular}

The effects of lead, crude ethanol extract and fractions of Solanum erianthum on the activities of creatinine, urea and total protein are shown in Table .9. The effects of vitamin E, lead, crude ethanol extract and ethyl acetate fraction of Solanum erianthum on the bilirubin and albumin levels of adult wistar rats are shown in Table 10 while the effects of lead and ethyl acetate fraction of Solanum erianthum on ALT and AST of adult Wistar rats are shown in the Table 12.

Table 10: Effect of Solanum erianthum on Bilirubin and Albumin Levels of Adult Wistar Rats.

\begin{tabular}{ccc}
\hline Group & $\begin{array}{c}\text { Total Bilirubin in } \\
\text { Plasma }(\mathbf{m g} / \mathbf{d l})\end{array}$ & $\begin{array}{c}\text { Total Albumin in } \\
(\mathbf{g} / \mathbf{d l})\end{array}$ \\
\hline A & $0.87 \pm 0.30$ & $4.05 \pm 0.49$ \\
B & $1.12 \pm 0.12$ & $4.77 \pm 0.67$ \\
C & $1.08 \pm 0.13$ & $4.11 \pm 0.17$ \\
D & $1.07 \pm 0.09$ & $3.75 \pm 0.20$ \\
E & $1.18 \pm 0.13$ & $3.77 \pm 0.21$ \\
F & $1.19 \pm 0.03$ & $4.11 \pm 0.37$ \\
G & $1.32 \pm 0.16$ & $3.50 \pm 0.40$ \\
\hline
\end{tabular}

Keys: $\mathrm{A}=$ Control

$\mathrm{B}=$ Toxicant Alone (Lead $10 \mathrm{mg} / \mathrm{kg}$ body weight $)$

$\mathrm{C}=$ Extract Alone $(100 \mathrm{mg} / \mathrm{kg}$ body weight $)$

$\mathrm{D}=$ Lead $(10 \mathrm{mg} / \mathrm{kg})+$ Ethyl Acetate Fraction $(100 \mathrm{mg} / \mathrm{kg}$ body weight $)$

$\mathrm{E}=$ Pre Lead $(10 \mathrm{mg} / \mathrm{kg})+$ Ethyl Acetate Fraction $(100 \mathrm{mg} / \mathrm{kg}$ body weight $)$

$\mathrm{F}=$ Post Lead $(10 \mathrm{mg} / \mathrm{kg})+$ Ethyl Acetate Fraction $(100 \mathrm{mg} / \mathrm{kg}$ body weight $)$

$\mathrm{G}=$ Lead $(10 \mathrm{mg} / \mathrm{kg})+$ Vitamin E $(100 \mathrm{mg} / \mathrm{kg}$ body weight $)$

Table 11: Effect of Solanum erianthum on Total Protein Levels of Adult Wistar Rats.

\begin{tabular}{|c|c|c|}
\hline Group & Total Protein in Plasma $(\mathrm{mg} / \mathrm{ml})$ & Total Protein in Liver $(\mathrm{mg} / \mathrm{ml})$ \\
\hline A & $3.01 \pm 0.26$ & $2.55 \pm 0.59$ \\
\hline B & $2.75 \pm 0.29$ & $1.94 \pm 0.05$ \\
\hline $\mathrm{C}$ & $2.33 \pm 0.17$ & $3.25 \pm 0.39$ \\
\hline $\mathrm{D}$ & $2.69 \pm 0.15$ & $2.23 \pm 0.37$ \\
\hline $\mathrm{E}$ & $2.71 \pm 0.22$ & $2.68 \pm 0.51$ \\
\hline $\mathrm{F}$ & $2.45 \pm 0.14$ & $4.16 \pm 0.26^{\mathbf{b}}$ \\
\hline $\mathrm{G}$ & $2.63 \pm 0.15$ & $4.45 \pm 0.19^{\mathbf{a}, \mathbf{b}}$ \\
\hline \multicolumn{3}{|c|}{$\begin{array}{l}\mathbf{a}=\text { significantly different from the control group at } \mathrm{p}<0.05 \\
\mathbf{b}=\text { significantly different from lead-treated group at } \mathrm{p}<0.05 \\
\mathbf{c}=\text { significantly different from extract-treated group at } \mathrm{p}<0.05\end{array}$} \\
\hline \multicolumn{3}{|c|}{$\begin{array}{l}\text { Keys: A = Control } \\
\text { B = Toxicant Alone (Lead } 10 \mathrm{mg} / \mathrm{kg} \text { body weight }) \\
\text { C = Extract Alone }(100 \mathrm{mg} / \mathrm{kg} \text { body weight }) \\
\mathrm{D}=\text { Lead }(10 \mathrm{mg} / \mathrm{kg})+\text { Ethyl Acetate Fraction }(100 \mathrm{mg} / \mathrm{kg} \text { body weight }) \\
\text { E = Pre Lead }(10 \mathrm{mg} / \mathrm{kg})+\text { Ethyl Acetate Fraction }(100 \mathrm{mg} / \mathrm{kg} \text { body weight }) \\
\mathrm{F}=\text { Post Lead }(10 \mathrm{mg} / \mathrm{kg})+\text { Ethyl Acetate Fraction }(100 \mathrm{mg} / \mathrm{kg} \text { body weight }) \\
G=\text { Lead }(10 \mathrm{mg} / \mathrm{kg})+\text { Vitamin E }(100 \mathrm{mg} / \mathrm{kg} \text { body weight })\end{array}$} \\
\hline
\end{tabular}

Table 12: Effect of Solanum erianthum on AST and ALT Levels of Adult Wistar Rats.

\begin{tabular}{|c|c|c|c|}
\hline Group & $\begin{array}{c}\text { ALT in Plasma } \\
(\mathbf{U} / \mathbf{L})\end{array}$ & $\begin{array}{c}\text { AST in Plasma } \\
(\mathbf{U} / \mathbf{L})\end{array}$ & $\begin{array}{c}\text { AST in Liver } \\
\text { (U/mg Protein) }\end{array}$ \\
\hline $\mathrm{A}$ & $2.01 \pm 0.50$ & $55.59 \pm 18.30$ & $145.40 \pm 2.91$ \\
\hline B & $8.25 \pm 1.07^{\mathrm{a}}$ & $90.61 \pm 2.82^{\mathrm{a}}$ & $83.77 \pm 2.26^{\mathbf{a}}$ \\
\hline $\mathrm{C}$ & $3.98 \pm 0.47^{\mathbf{b}}$ & $43.26 \pm 10.27^{b}$ & $154.20 \pm 1.20^{\mathrm{b}}$ \\
\hline $\mathrm{D}$ & $4.46 \pm 1.17$ & $74.10 \pm 7.82$ & $159.00 \pm 3.99^{b}$ \\
\hline $\mathrm{E}$ & $5.13 \pm 1.03$ & $45.66 \pm 5.26^{\mathbf{b}}$ & $121.80 \pm 19.88^{b}$ \\
\hline $\mathrm{F}$ & $2.48 \pm 0.77^{\mathbf{b}}$ & $53.02 \pm 3.23^{b}$ & $130.10 \pm 2.23^{\mathbf{b}}$ \\
\hline $\mathrm{G}$ & $3.20 \pm 0.37^{\mathbf{b}}$ & $49.32 \pm 2.63^{b}$ & $134.00 \pm 3.74^{\mathbf{b}}$ \\
\hline \multicolumn{4}{|c|}{$\begin{array}{l}\mathbf{a}=\text { significantly different from the control group at } \mathrm{p}<0.05 \\
\mathbf{b}=\text { significantly different from lead-treated group at } \mathrm{p}<0.05 \\
\mathbf{c}=\text { significantly different from extract-treated group at } \mathrm{p}<0.05\end{array}$} \\
\hline \multicolumn{4}{|c|}{$\begin{array}{l}\text { Keys: } \mathrm{A}=\text { Control } \\
\mathrm{B}=\text { Toxicant Alone (Lead } 10 \mathrm{mg} / \mathrm{kg} \text { body weight }) \\
\mathrm{C}=\text { Extract Alone }(100 \mathrm{mg} / \mathrm{kg} \text { body weight }) \\
\mathrm{D}=\mathrm{Lead}(10 \mathrm{mg} / \mathrm{kg})+\text { Ethyl Acetate Fraction }(100 \mathrm{mg} / \mathrm{kg} \text { body weight }) \\
\mathrm{E}=\text { Pre Lead }(10 \mathrm{mg} / \mathrm{kg})+\text { Ethyl Acetate Fraction }(100 \mathrm{mg} / \mathrm{kg} \text { body weight }) \\
\mathrm{F}=\text { Post Lead }(10 \mathrm{mg} / \mathrm{kg})+\text { Ethyl Acetate Fraction }(100 \mathrm{mg} / \mathrm{kg} \text { body weight }) \\
\mathrm{G}=\mathrm{Lead}(10 \mathrm{mg} / \mathrm{kg})+\text { Vitamin E }(100 \mathrm{mg} / \mathrm{kg} \text { body weight })\end{array}$} \\
\hline
\end{tabular}

Additionally the histomorphological changes in the kidneys and liver of test animals are shown in Plate 1 and Plate 2 respectively. 

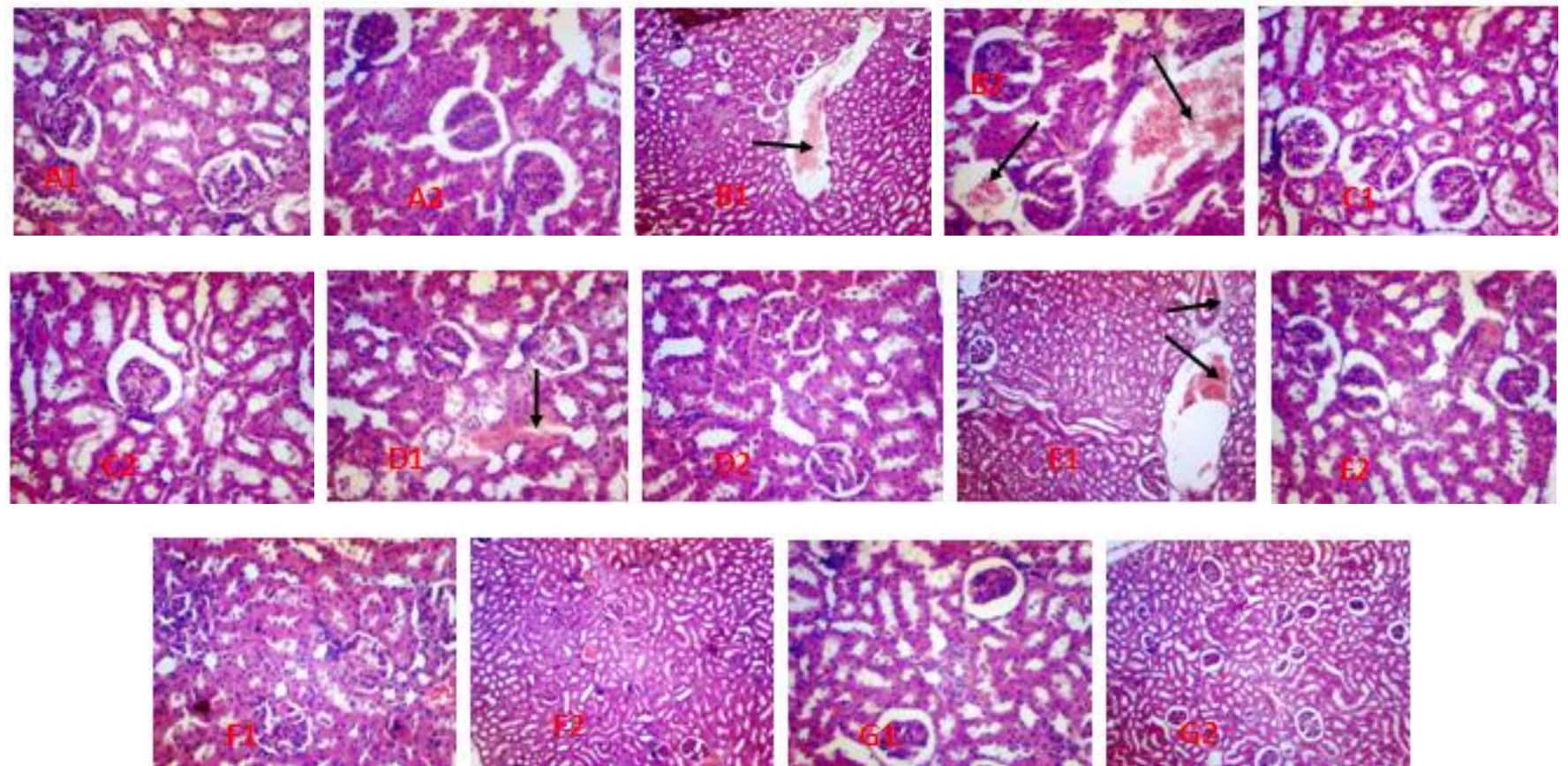

Plate 1: Photomicrographs of the uriniferous tubules of groups A, B, C, D, E, F and G showing glomerulus and Bowman's capsules while the arrows showing affected parts Stain H\&E. Mag. X400.
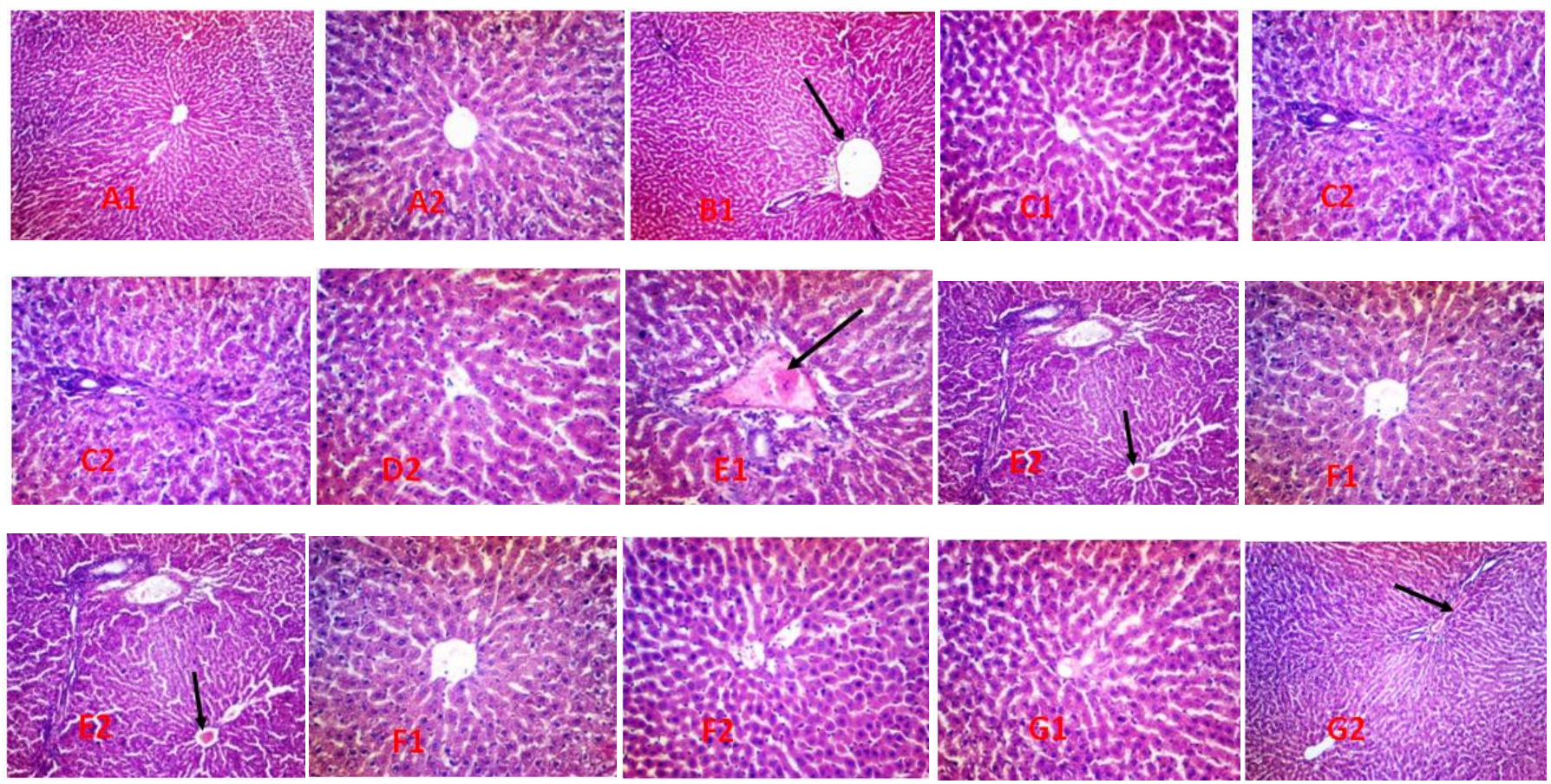

Plate 2: Photomicrographs of liver tubules of groups A, B, C, D, E, F and G showing different liver sinusoids while the arrows showing affected parts Stain H\&E. Mag. X400. 


\section{DISCUSSION}

The non biodegradable nature of lead is the prime reason for its prolonged persistence in the environment and this has led to a manifold increase in the occurrence of free lead in biological systems and the inert environment (Flora et al., 2012). Lead causes generation of reactive oxygen species (ROS) which results in critical damage to various biomolecules like DNA, enzymes, proteins and membrane based lipids, while simultaneously it impairs the antioxidant defense system. It has also been reported that lead increases the level of lipid peroxidation (Upasani et al., 2001). Oxidative stress has been found to be more pronounced and much more severe in various molecular, cellular and intercellular mechanisms proposed to explain the toxicological profile of lead. Various naturally occurring antioxidants (nutrient antioxidants) like vitamins, flavonoids and herbal antioxidants have been reported for the prevention and treatment of lead induced toxicity and oxidative stress in particular. They have the ability to scavenge ROS at molecular level and chelate lead ions, thereby reversing the toxic effects of lead (Flora et al., 2012).

The phytochemical screening of the crude ethanol extract and fractions of $S$. erianthum showed the presence of the following secondary metabolites: alkaloids, cardiac glycoside, flavonoids, saponins, tannins, triterpenes and steroids and this is in agreement with the phytochemical screening reported on the same plant by Bhargavi et al. (2012), Archana et al. (2013) and Sujatha et al. (2013). All the above mentioned secondary metabolites were present in the crude ethanol extract.

The antioxidant potential and screening of S. erianthum ethanol extract and fractions were assessed using various biological parameters and compared with the standard antioxidants. In this study, ethyl acetate fraction of $S$. erianthum contained the highest total flavonoid concentration while aqueous fraction contained the least flavonoid concentration. This was perfectly in agreement with the report of Sujatha et al. (2013). It has been established that flavonoids from medicinal plants possess high antioxidant potentials due to their hydroxyl groups and protect more efficiently against free radical related diseases like hepatotoxicity, cardiovascular diseases, kidney diseases, arteriosclerosis, etc (Kris-Etherton et al., 2002; Vaya et al., 2003). Flavonoids are also involved in scavenging of oxygen derived free radicals (Nijveldt et al., 2001). The major phenolic compounds (flavonoids and tannins) play major roles as antioxidant capacity of plants and biological activities of plants may be related to their antioxidant potentials, tannins contributed a major role as antihaemorrhagic, antihypercholesterol, hypotensive and cardiac depressant agent (Price et al., 1987), steroids, terpenoids and saponins were reported to have analgesic, hypocholesterolemic, anti-diabetic properties (Rupasinghe et al., 2003; Sayyah et al., 2004; Malairajan et al., 2006). It is therefore possible that the presence of flavonoids and tannins in the plant extract/fractions might be responsible for the free radical scavenging effects observed, since flavonoids and tannins are the major phenolic compounds that act as free radical scavengers. In the study, ethyl acetate fraction contained the highest concentration of phenol content while $\mathrm{n}$-hexane fraction contained the least concentration of phenol content. Phenolic compounds are different in molecular structure, and are characterized by hydroxylated aromatic rings (Balasundram et al., 2006).

Free radical scavenging potential of $S$. erianthum extract and fractions at different concentrations was evaluated by the DPPH method. Antioxidant reacts with DPPH, which is a stable free radical, and converts it to 1, 1-diphenyl-2-picrylhydrazine. The highest scavenging activities (or percentage inhibition) were observed in ethyl acetate fraction. The strong inhibition displayed on DPPH radicals could be linked to polyphenolic compounds which are capable of donating electrons or transferring hydrogen atoms to neutralize free radicals (Huang et al., 2005) and thus, could be a promising therapeutic agent to address stress induced pathological conditions.

The FRAP assay (ferric reducing ability of plasma) evaluates total antioxidant power and is chosen to assess the presumable effects of medicinal plants (Szollosi and Varga, 2002). FRAP method is sensitive in the measurement of total antioxidant power of the fresh biological fluids, such as plant homogenates and pharmacological plant products (Szollosi and Varga, 2002; Rattanachitthawat et al., 2010). In the present study, the highest ferric reducing power activity was observed in ethyl acetate fraction. This suggests that the presence of reductants within the ethyl acetate fraction of $S$. erianthum play an important role in scavenging the free radicals i.e. the reducing ability of polyphenolic compounds within the ethyl acetate fraction that exhibit antioxidative potentials in breaking the free radical chain and donating a hydrogen atom may be responsible for their scavenging power.

The results of the acute toxicity studies showed that the $\mathrm{LD}_{50}$ is greater than $5000 \mathrm{mg} / \mathrm{kg}$ body weight and the crude ethanol extract of $S$. erianthum is therefore safe at a dose lower than $5000 \mathrm{mg} / \mathrm{kg}$. The result obtained here is in agreement with that of Archana et al. (2013) on the same plant. This suggests that the extract at the limit dose is therefore non-toxic and safe in oral formulations.

Exposure of red blood cells to injurious substances such as a hypotonic medium results in lysis of its membrane accompanied by haemolysis and oxidation of haemoglobin (Augusto et al., 1982). Lysosomal hydrolytic enzymes are released during inflammation into the sites which cause damage to the surrounding organelles and tissues with attendant variety of disorders (Sadique et al., 1989; Oyedapo et al., 2010). The haemolytic effect of hypotonic solution is related to excessive accumulation of fluid within the cell resulting in the rupture of its membrane. Injury to red blood cell membranes will further render the cells more vulnerable to secondary damage through free radical-induced lipid peroxidation (Augusto et al., 1982; Ferrali et al., 1992). This mean that break down of bio-membranes leads to the formation of free radicals which in turn enhances cellular damage (Maxwell, 1995). It is therefore expected that compounds with membrane-stabilizing properties, should offer significant 
protection to cell membrane against injurious substances (Liu et al., 1992; Maxwell, 1995; Shinde et al., 1999). Since the viability of cells depends on the integrity of their membranes (Ferrali et al., 1992), therefore, the anti-inflammatory action of $S$. erianthum on red blood cell (RBC) membranes stabilization was carried out in order to establish its anti-inflammatory potentials. The ethanol extract exhibited and provided highest protection against induced lyses and all the fractions and the crude ethanol extract showed dose dependent membrane stabilizing activity across the concentration ranges. The mode of response of the erythrocyte was biphasic. This was followed by ethyl acetate fraction and the mode of response of the erythrocyte was monophasic. Hexane fraction gave the least membrane stabilizing potential of all the fractions. The results indicated that all the fractions contained principles that protect and stabilize the erythrocyte effectively. The activities of the crude ethanol extract and that of ethyl acetate fraction were higher than the standard drug (diclofenac) used, even at lower concentration ranges. Moreover, the stabilization of lysosomal membrane is crucial in reducing or limiting the inflammatory response by preventing the release of the activated neutrophil, which can cause tissue damage upon extra cellular release (Oyedapo et al., 2004). Since erythrocyte membrane is analogous to the lysosomal membrane, its stabilization means that the extract may stabilize the lysosomal membrane too.

Liver plays a major role in metabolism and has a number of functions in the body which includes glycogen storage, decomposition of red blood cells, plasma protein synthesis, and hormone production, metabolism of xenobiotics and excretion of waste materials. Most injected agents pass through the liver before entering the general circulation (Matoni et al., 1993). Kidneys on the other hand, remove waste products, many of which are toxic, from the blood and also play a major role in controlling blood volume, the concentration of ions in the blood, and the $\mathrm{pH}$ of the blood. The kidneys are also involved in the control of red blood cells production and vitamin D metabolism. Liver damage could be confirmed by changes in the activities of hepatic enzymes in serum or plasma by their increased or decreased synthesis, released from damaged cells and extra-hepatic tissue (Chawla, 1999). Significant changes in the activities of plasma and liver albumin, bilirubin, aspartate aminotransferase (AST), and alanine aminotransferase (ALT) levels are indices good for detecting liver damage (Boelsterli, 2003). Chronic exposure of kidney to lead may cause nephrotoxicity characterized by glomerular sclerosis, interstitial fibrosis and proximal tubular nephropathy (ATSDR, 2007).

In the present study, oral administration of lead (10 $\mathrm{mg} / \mathrm{kg}$ body weight) caused a marked decrease in percentage change in weight of lead-treated groups as compared with that of controls and extract alone.

Plasma creatinine concentration was significantly high in group treated with lead alone. Bazari (2007) reported that high creatinine level than normal might be due to kidney dysfunction while lower than normal levels indicates late muscular dystrophy and myasthenia gravis. The changes observed in plasma creatinine levels of rats treated with lead alone may suggest kidney damage. There was significant elevation in the plasma urea activities of the rats treated with lead alone which is an indication of renal impairment (Murray et al., 2003). The elevation in the plasma urea level might probably be due to impairment in the excretory function of the kidney possibly as a result of ingested lead.

There was significant decrease in the levels of kidney total protein in pre-treatment and positive control groups as compared to other groups. Measurement of total bilirubin includes both unconjugated and conjugated bilirubin. High levels of total bilirubin in lead-treated groups as compared to other groups were observed occasioned by the treatment with lead which suggests inability of the liver to metabolize bilirubin further confirming liver dysfunction, which might have been caused by haemolysis of red blood cells (Chawla, 1999).

Albumin is the major protein of the plasma and is responsible for the transportation of the fatty acids and bilirubin through the bloodstream to the liver. The synthesis of albumin is depressed in a variety of diseases, particularly those of the liver (Murray et al., 2003). Since albumin levels in group treated with lead alone were abnormally higher than other groups, it means that the transportation of materials within the blood stream might have been affected as well as the liver integrity.

There was a decrease in both the liver and plasma total protein concentrations in lead treated rats compared with control rats. It could be inferred that significant increase in plasma total protein levels as can be seen in intervention groups (i.e. groups D through $\mathrm{G}$, table 3.11) might be the means through which the treated rats compensated for the production of enzyme or protein lost as a result of tissue necrosis or means to meet increase demand to detoxify the lead toxicity. This observation was in line with the results of Hassanin (1994) and El-Zayat et al. (1996) who found a decrease in hepatic total protein content in response to lead intoxication. They attributed that to a decreased utilization of free amino acids for protein synthesis. Pagliara et al. (2003) showed that lead-induced liver hyperplasia followed by apoptosis mediated by oxidative stress in kupffer cells. Also, it induced apoptosis in the germ cells within the seminiferous tubules (Adhikari et al., 2001) and in rod photoreceptors (He et al., 2003). Iavicoli et al. (2001) demonstrated that the induction of apoptosis contributes to the lead-induced inhibition of cell proliferation in rat fibroblasts. While the observed marked decrease in liver total protein concentration in group treated with lead alone could be attributed to inability of protein synthesizing machinery to be able to function properly as occasioned by higher concentration of lead in lead treated group. The moderate decrease observed in the levels of plasma total protein (table 3.11) might be a deliberate insult on the liver since all conditions that affect the liver, such as hepatitis, etc will cause the protein level in the blood to decrease. This is due to the fact that the liver is the organ that is responsible for producing protein.

In the study, the plasma alanine aminotransferase (ALT) activity increased significantly $(p \leq 0.05)$ in group treated with lead alone. Change observed in plasma transaminase activities in 
the treated rats is speculated to be a reflection of liver damage occasioned by ingestion of lead. The post-lead treated group favourably competed with the positive control (vitamin E). Similarly, there was a significant increase in plasma AST in group treated with lead alone than any other group. It was also seen here that the post-lead treated group favourably competed with the positive control group. Significant changes in the activities of plasma and liver aspartate aminotransferase (AST), alanine aminotransferase (ALT) levels are indices good for detecting liver damage (Boelsterli, 2003).

The histology evidence from the study indicated the occurrence of a progressive degeneration of the liver and kidney tissues most especially in group treated with lead alone. However, histological study of the kidney and liver showed well arranged uriniferous tubules and hepatic sinusoids with distinct interstitial in control rats. Although, there were histology abnormalities; varying degree of cellular degeneration within the renal and hepatic tubules in rats challenged with lead which was obvious in rats treated with lead alone. There was also marked destruction of hepatic cells and uriniferous tubules in rats treated with lead and ethyl acetate fraction of Solanum erianthum with little or partial restoration of the peripherial tissues. This damage was characterized by necrosis and destruction of the uriniferous and hepatic tubules indicating the reduced ability of the kidneys to function properly to eliminate water-soluble chemicals that are removed from the blood by the process of reverse filtration, with complete restoration in post lead and positive control (vitamin E) treated groups.

In conclusion, marked degeneration of liver and kidney tissues could be attributed to ingestion of lead $(10 \mathrm{mg} / \mathrm{kg}$ body weight) which were recovered by the use of the plant extract in reversing the altered biochemical variables that could be useful in enhancing endogenous antioxidant levels as can be seen in the histology evidence that confirmed the protective role of $S$. erianthum on various lead-induced histopathological injuries in the rat liver and kidney. Hence it could be surmised that the ethyl acetate fraction of $S$. erianthum exhibits very high mitigating potentials in lead associated nephrotoxicity and hepatotoxicity.

Nevertheless, further investigations on this fraction are hereby suggested to decode the specific phytochemical constituent(s) responsible for the antioxidant activities of the plant.

\section{Financial support and sponsorship: Nil.}

Conflict of Interests: There are no conflicts of interest.

\section{REFERENCES}

Adhikari N, Sinha N, Narayan R, Soxena, DK.. Lead-induced cell death in testes of young rats. J. Appl. Toxicol, 2001; 21(4): 275-277. Afify AMR, El-Beltagi HS. Effect of the insecticide cyanophos on liver function in adult male rats. FEB, 2011; 20(4a): 1084-1088. Archana, BJ, Shah CS. Evaluation of Anti-Diarrhoeal Activity of Root Bark of Solanum erianthum (D. Don). UJP, 2013; 2(03): 89-93. ATSDR. 2007. Toxicological Profile for Lead. US Department of Health and Human Services: Atlanta, US. Augusto O, Kunze, KL, Montellano, PR. Nphenylprotoporphyrin formation in the haemogolobin-phenylhydrazine reaction. J Biol Chem, 1982; 257: 6231-6241.
Balasundram N, Sundram K, Saman S. Phenolic Compounds in Plants and Agro industrial by-Products: Antioxidant Activity, Occurrence, and Potential Uses. Food Chem, 2006; 99: 191- 203

Bazari H. 2007. Approach to the patient with renal disease, In: Goldman L, Ausiello D, (Eds), Cecil Medicine. 23rd edition. Saunders Elsevier, Philadelphia, pp. 115.

Benzie IFF, Strain JJ. Ferric reducing/antioxidant power assay: direct measure of total antioxidant activity of biological fluids and modified version for simultaneous measurement of total antioxidant power and ascorbic acid concentration. Methods Enzymol, 1999; 299: 15-27.

Bhargavi CS, Swamy V, Bilal S, Ushasri S, Kumar R. Wound Healing Activity of Alcoholic Extract of Solanum erianthum D. Don in Excision and Incision Method. Int J Res Ayurveda Pharm, 2013; 4(1).

Blois MS. Antioxidant determinations by the use of a stable free radical. Nature, 1958; 181: 199-200.

Boelsterli UA. Idiosyncratic drug hepatotoxicity revisited: new insights from mechanistic toxicology. Toxicol Mech Methods, 2003;13: 3-20.

Brace JL. SVfi inhibits reactive oxygen species generation and promote survival under conditions of oxidative stress in Saccharomyces cerevisiae. Yeast, 2001; 22(8): 641-652.

Chawla R. 1999. In Practical Clinical Biochemistry: Methods of Interpretations. Second edition. Medical Publishers India pg100-132.

El-Zayat EM, El-Ymany NA, Kamel ZH. Combined supplementation of zinc and Vitamin $\mathrm{C}$ as protective agents against lead toxicity in growing male albino rats. JEGSZ, 1996; 20 (A): 115-139.

Essien EE, Ogunwande, IA, Setzer WN, Ekundayo, O. Chemical composition, antimicrobial, and cytotoxicity studies on $S$. erianthum and S. macranthum essential oils. Pharm Biol, 2012; 50(4): $474-480$.

Felger RS, Matthew BJ, Michael FW. 2001. The Trees of Sonora, Mexico. Oxford University Press. p. 315.

Ferrali M, Signorni C, Ciccoli L, Comporti M. Iron release and membrane damage in erythrocytes exposed to oxidizing agents, phenylhydrazine, divicine and isouramil. Biochem J, 1992; 285: 295-301.

Flora SJS, Flora G, Saxena G. Environmental occurrence, health effects and management of lead poisoning" In: Cascas SB, Sordo J, editors. Lead chemistry, analytical aspects, environmental impacts and health effects. Netherlands, 2006; 158-228.

Flora SJS, Gautam P, Dwivedi N. Dose dependent effects of ethanol on lead induced oxidative stress in rats. J Environ Pathol Toxicol Oncol, 2012; 31: 61-73.

Flora SJS, Pachauri V, Saxena G. Arsenic, cadmium and lead, Reproductive and Developmental Toxicology. Academic Press, 2011; 415-438.

Foyer $\mathrm{CH}$, Noctor G. Oxygen processing in photosynthesis: regulation and signaling. New Phytol, 2002; 146: 359-388.

Gornall AG, Bardwill CJ, David MM. Protein determination with Biuret reagent. J Biol Chem, 1949; 117: 751-756.

Gulcin I, Oktay M, Kirecci E, Kufreviolu I. Screening of antioxidant and antimicrobial activities of anise (Pimpella anisum L.) seed extracts. Food Chem, 2003; 83: 371-382.

Hammer RL, 2004. Florida Keys Wildflowers: A Field Guide to Wildflowers, Trees, Shrubs, and Woody Vines of the Florida Keys. Globe Pequot. Pp: 205. ISBN 9780762725694.

Hassanin LAM, 1994. The effect of lead pollution on the susceptibility of rats to anticoagulants rodenticides. M.Sc. Thesis. Zoology Department, Faculty of Science, Cairo University, Giza, Egypt.

He L, Perkins GA, Poblenz AT, Harris JB, Hung M, El-lisman MH, Fox DA. Bcl-xL over expression blocks Bax-mediated mitochondrial contact site formation and apoptosis in rod photoreceptors of lead-exposed mice. Proc Natl Acad Sci U S A, 2003; 100(3): 1022-1027.

Huang DJ, Ou BX, Prior RL. The chemistry behind antioxidant capacity assays. J Agric Food Chem, 2005; 53: 1841-1856.

Iavicoli I, Sgambato A, Carelli G, Ardito R, Cittadini A, Castellino N. Lead-related effects on rat fibroblasts. Mol Cell Biochem, 2001; 222 (1-2): 35-40.

Ibrahim NM, Eweis EA, El-Beltagi HS, Abdel-Mobdy YE. Effect of lead acetate toxicity on experimental male albino rat. Biol Trace Elem Res, 2012; 144(1-3): 1120-1132. 
Jendrassik L, Grof P. .Estimation of total serum bilirubin level by spectrophotometrically in serum and plasma. J Cli Chem Cli Biochem, 1938; 297: 81-89.

Kris-Etherton PM, Hecker KD, Bonanome A, Coval SM, Binkoski, AE, Hupert KF, Griel AE, Etherton TD. Bioactive compounds in foods: their role in the prevention of cardiovascular disease and cancer. Am J Med, 2002; 113: 71-88.

Liu GT Zhang TM, Wang BE, Wang YW. Protective action of seven natural phenolic compounds against peroxidative damage to biomembranes. Biochem Pharmacol, 1992; 43: 147-152.

Lorke DA. A new approach to practical acute toxicity testing. Arch Toxicol, 1983; 54: 275-287.

Mahadev R, Ramakrishnaiah H, Krishna V, Naveen, KN, Deepalakshmi, AP. In vitro Antioxidant Activity of Methanolic Extracts of Solanum erianthum D. Don. Inter J Pharm, 2015; 5(1): 238-243

Malairajan P, Geetha G, Narasimhan S, Jessi-Kala VK. Analgesic activity of some Indian medicinal plants. J Ethnopharmacol, 2006; 19: 425-428

Malecka A Jarmuszkiewicz W, Tomaszewska B. Antioxidative defense to lead stress in sub cellular compartments of pea root cells. Acta Biochim Pol, 2001; 48: 687-698.

Matoni R, Travis L, Cor Z, Vojtech, N. Analysis of transec counts to monitor population size in endangered insects: The case of the El Segundo Blue butterfly, Euphilotes Bernardino allyni. J Insect Conserv, 1993; 5: 197-206.

Maxwell SRJ. Prospects for the use of anti-oxidant therapies. Drugs, 1995; 49: 345-361.

Mild C. 2009. Wonderful and Woody Shrubs of the Water's Edge.and Beyond (PDF). Native Plant Project.

Miliauskas G, Venskutonis PR, van-Beek, TA. Screening of radical scavenging activity of some medicinal and aromatic plant extracts. Food Chem, 2004; 85: 231-237.

Modise DM, Mogotsi, KK. 2008. Solanum erianthum D. Record from PROTA4U. PROTA (Plant Resources of Tropical Africa / Ressources végétales de l'Afrique tropicale) [ed. by Schmelzer, G. H. IGurib-Fakim, A.]. Wageningen, Netherlands: PROTA.

Murray RK., Granner, DK, Mayes, PA, Rodwell, VW. 2003. Harper's Illustrated Biochemistry. 26th ed. Lange medical Books/ McGraw-Hill.

Naha N, Chowdhury, AR. Toxic effect of lead on human spermatozoa: A study among pigment factory workers. Indian J Occup Environ, 2005; 9: 118-23.

Nijveldt, RJ, Nood EV, Hoorn DE, Boelens PG, Norren KV, Paul AM, Leeuwen V. Flavonoids: a review of probable mechanism of action and potential applications. Am J Cli Nutr, 2001; 74: 418-425.

Oyedapo OO, Akinpelu BA, Orefuwa, SO. Anti-inflammatory effect of Threobama cacao, root extracts. JTMP, 2004; 5(2): 161-165.

Oyedapo OO, Akinpelu BA, Akinwunmi KF, Adeyinka MC, Sipeolu FO. Red blood cell membrane stabilizing potentials of extracts of Lantana camara and its fractions. Int J Plant Physiol, 2010; 2(4): 46-51.

Pagliara P, Chionna A, Carla EC, Caforiao S, Dini L. Lead nitrate and gadolinium chloride administration modify hepatocyte cell surfaces. Cell Tissue Res, 2003; 312(1): 41-48.

Pinnell AE, Northam BE. New automated method for serum albumin determination with bromocresol purple. Clin Chem, 1978; 24: 8086.

Price KK, Johnson LI, Fenwick D. The chemical and biological significance of saponins in food and feeding stuffs. Food Sci Nutr, 1987; 26: $27-135$

Rattanachitthawat S, Suwannalert P, Riengrojpitak S, Chaiyasut, C, Pantuwatana, S. Phenolic content and antioxidant activities in red unpolished Thai rice prevents oxidative stress in rats. J Med Plant Res, 2010; 4(9): 796 - 801.

Reitman S, Frankel S. A calorimetric method for the determination of serum glutamic oxaloacetic acid and glutamic pyruvic transaminases, Am J Clin Pathol, 1957; 28: 56-63.

Rupasinghe HP, Jackson CJ, Poysa, V, Di-Berado C, Bewley JD, Jenkinson J. Soyasapogenol A and B distribution in Soybean (Glycine
Max L.Merr) in relation to seed physiology, genetic variability and growing location. J Agric Food Chem, 2003; 51: 5888-5894.

Sadique J, Al-Rqodah, WA, Baghhath, MF, El-Ginay RR. The bioactivity of certain medicinal plants on the stabilization of the RBC system. Fitoterapia (Italy), 1989; LXVI: 525-532.

Sayyah M, Hadidi, N, Kamalinejad, M. Analgesic and antiinflammatory activity of Lactuca sativa seed extract in rats. J Ethnopharmacol, 2004; 92: 325-329.

Shalan, MG, Mostafa MS, Hassouna MM, El-Nabi SE, ElRefaie A. Amelioration of Lead Toxicity on Rat Liver with Vitamin C and Silymarin Supplements. Toxicology, 2005; 206(1): 1-15.

Shehab, G. M. G, Ahmed OK, El-Beltagi HS. Nitric oxide treatment alleviates drought stress in rice plants (Oryza sativa). Not Bot Agrobot Cluj-Napoca, 2010; 38(1): 139-148.

Shinde UA, Phadke AS, Nair AM, Mungantiwar AA, Dikshit VJ, Saraf, VO. Membrane stabilizing activity-a possible mechanism of action for the anti-inflammatory activity of Cedrus deodara wood oil. Fitoterapia, 1999; 70: 251-257.

Sidhu P, Nehru B. Lead intoxication: Histological and oxidative damage in rat cerebrum and cerebellum. J Trace Elem Med, 2004; 17(1) 45-53.

Singleton VL, Rossi JA. Colorimetry of total phenolics with phosphomolybdic phosphotungustic acid reagent. Am J Enol Vitic, 1965; 16: $144-158$

Sofowora A. 2006. Screening plants for bioactive agents, In: Medicinal plants and traditional medicine in Africa. Third Edition, Spectrum Books Limited, Ibadan, Nigeria. pp 150-153.

Sujatha V, Priyadharshini DS. Antioxidant profile and GC-MS analysis of Solanum erianthum leaves and stem- A comparison. Int J Pharm Pharm Sci, 2013; 5(3): 652-658.

Szollosi R, Varga, IS. Total antioxidant power in some species of Labiatae (Adaptation of FRAP method). Acta Biol Szeged, 2002; 46(34): $125-127$

Upasani CD, Khera A, Balaraman R. Effect of lead with Vitamins E, C, or Spirulina on malondialdehyde: conjugated dienes and hydroperoxides in rats. Indian J Exp Biol, 2001; 39(1): 70-74

Vaya J, Mahmoud S, Goldblum A, Aviram M, Volkova N, Shaalan A, Musa R, Tamir S. Inhibition of LDL oxidation by flavonoids in relation to their structure and calculated enthalpy. Phytochemistry, 2003; 62: 89-99.

Weatherburn MW. Phenol-hypochlorite reaction for determination of ammonia. Ann Chem, 1967; 39: 971-974.

Xienia U, Foote GC, Van S, Devreotes PN, Alexander S, Alexander $\mathrm{H}$. Differential developmental expression and cell type specificity of Dictyostelium catalases and their response to oxidative stress and UV light. Biochim Biophys Acta, 2000; 1492: 295-310.

Zhilen J, Mengeheng T, Jiamming W. The determination of flavonoid content in mulberry and their scavenging effects on superoxide radicals. Food Chem, 1999; 64: 555-559.

\section{How to cite this article:}

Agbi AJ, Badiora AS, Areola JO, Babalola OO. Protective Effects of Solanum Erianthum D. Don Leaf Extract on Lead-Induced Toxicity in Adult Wistar Rats. J App Pharm Sci, 2016; 6 (10): 113 123. 